\title{
A Spatiotemporal Assessment of Land Use and Land Cover Changes in Peri-Urban Areas: A Case Study of Arshaly District, Kazakhstan
}

\author{
Onggarbek Alipbeki ${ }^{1, *(1)}$, Chaimgul Alipbekova ${ }^{2}$, Arnold Sterenharz ${ }^{3}$, Zhanat Toleubekova ${ }^{1}$, \\ Meirzhan Aliyev ${ }^{1}$, Nursultan Mineyev ${ }^{1}$ and Kaiyrbek Amangaliyev ${ }^{1}$ \\ 1 Department of Land use and Geodesy, S.Seifullin Kazakh Agro Technical University, Zhengis avenue, 62, \\ Nur-Sultan 010000, Kazakhstan; jtoleubekova@mail.ru (Zh.T.); meirzhan.maratuly@mail.ru (M.A.); \\ nursultan_23@list.ru (N.M.); kairbek1202@gmail.com (K.A.) \\ 2 Department of Plant protection and Quarantine, S.Seifullin Kazakh Agro Technical University, \\ Zhengis avenue, 62, Nur-Sultan 010000, Kazakhstan; chaimgul@mail.ru \\ 3 EXOLAUNCH GmbH, Reuchlin str. 10, 10553 Berlin, Germany (Spin-off Company from the Technical \\ University of Berlin, Germany); arnold.st@exolaunch.com \\ * Correspondence: oalipbeki@mail.ru; Tel.: +7-7715369615
}

Received: 14 January 2020; Accepted: 16 February 2020; Published: 19 February 2020

check for updates

\begin{abstract}
In this study, the spatiotemporal dynamics of land use and land cover (LULC) were evaluated in the peri-urban area of the Arshaly district, which borders the capital of the Republic of Kazakhstan. Landsat multispectral images were used to study the changes in LULC. The analysis of LULC dynamics was carried out using supervised classification with a multi-temporal interval $(1998,2008$, and 2018). During the study period, noticeable changes occurred in LULC. There was an increase in the area of arable land and forests and a reduction in the pastures. There was a sharp increase in the built-up area; that is, there was an intensification of land use through an increase in the share of arable land as well as the transformation of agricultural land for development. However, in general, the influence of urban sprawl in this peri-urban area has so far been accompanied by only a slight focus on its sustainable development.
\end{abstract}

Keywords: land use and land cover; remote sensing; supervised classification; change detection; driving factors; Arshaly district

\section{Introduction}

Urban sprawl has been observed throughout the world, and there is concern about its impact on peri-urban areas (PUAs) [1-3]. Often, peri-urbanization occurs spontaneously with unpredictable consequences and casts doubt on the sustainable development of a region. It has been established that the growth and development of a large city and its interaction with the PUA are influenced by three main factors: economic development, the intensity of trade growth, and political motivation on the part of the state aimed at the growth and development of cities [4]. As for the city of Nur-Sultan (Tselinograd, Akmola, Astana), which is the capital of Kazakhstan, and the surrounding areas, all three of the above factors work quite effectively. For example, over the past 20 years (1998-2018), the capital of Kazakhstan transformed from a provincial regional city into a large metropolis as a result of the combined impact of the above three factors and became the political, economic, and cultural center of the republic [5]. In the adjacent agro-industrial areas, under the influence of the metropolis, certain changes also took place during the study period, both under the influence of urban sprawl [6] and other factors [7], which still require analysis and evaluation. 
As a rule, urban expansion is associated with a loss or change in the intensity of use of agricultural lands [3,8-12]. Therefore, the assessment of changes occurring in the PUA is mainly carried out through studies of changes in land use and land cover (LULC) [13]. Information on changes in the LULC structure is vital for the proper planning, management, and use of natural resources as well as for protecting the environment [14]. Assessing LULC changes helps to better understand the relationship between people and the environment to optimally manage resources and to use them for sustainable development $[15,16]$. Therefore, tracking systems for the process of LULC have been created using remote sensing (RS) at different levels [17]. Of particular importance is the instrumental assessment of the long-term spatiotemporal changes of LULC in the PUAs that are under their influence $[18,19]$, which explains the need to increase the number of studies in this direction [20].

Land use and land cover are two different terms that are usually evaluated in combination since the former (physical properties of surface elements) and the latter (human use of land cover) cannot be considered independent of each other [21]. Thus, LULC is the result of human interaction with the environment, which is affected by changes in socioeconomic processes. By assessing changes in the long-term structure of LULC and by focusing on the main processes, it is possible to determine the drivers of these phenomena and to take effective measures for the sustainable development of the area of interest (AOI) [22].

There are many methods and tools for classifying and evaluating LULC variations. In particular, the use of multiple RS data provides continuous and accurate LULC status information. RS data, combined with geographic information systems (GIS), are used to assess LULC changes in a wide range of natural resource parameters at the local level [23-25], including agricultural land in PUAs. In Kazakhstan, intensive land-use studies, including RS- and GIS-based studies, started in the 1990s [26]. In the initial stages, these studies mainly aimed at preliminary assessments of damage from ineffective land use during the Soviet era, which led to serious environmental consequences of, for example, the Aral Sea, the former Semipalatinsk nuclear test site, the Baikonur cosmodrome, and the development of minerals and hydrocarbons, etc. [27-31]. An active study of land use in the northern grain-growing regions of the republic was launched in 2002 when the first project funded by the Ministry of Agriculture of Kazakhstan started monitoring the timing of crops and forecasting the future harvest of annual grain crops and the completeness of their harvesting [32]. As a rule, land-monitoring research within the grain region ended with the fulfilment of the objectives of each study year. In connection with the advent of Kazakhstan's space system [33], the number of objects subject to annual satellite monitoring has gradually expanded [34,35]. When assessing the impact of various factors on land use, RS and GIS methods are most often used (52\%) [36]. There are currently studies underway using RS and GIS data to study long-term changes in LULC in individual regions of the country. These works are devoted to the study of land-use changes outside the direct influence of urban sprawl [37-40] or only in the city itself [41]. At the same time, a comprehensive assessment of the impact of large cities of Kazakhstan on the surrounding agricultural areas using long-term spatiotemporal data series remains open for determining sustainable development approaches for both cities and PUAs.

Based on the preceding, our main goal was to identify drivers that affect LULC change in the Arshaly district, which borders the Nur-Sultan metropolis. The objectives of the study were to evaluate the changes in LULC in the AOI based on the use of multitemporal RS data $(1998,2008$, and 2018) as well as to assess the degree and consequences of the influence of these drivers on the sustainable development of this PUA.

\section{Materials and Methods}

\subsection{Study Area}

The research area selected was the Arshaly district, Akmola oblast, which is located on the eastern border of the capital of the Republic of Kazakhstan, the city of Nur-Sultan. Previously, Nur-Sultan was called Tselinograd, Akmola, and Astana. The AOI is limited by the following longitudes and 
latitudes: in the north, $72^{\circ} 08^{\prime} 06,4^{\prime \prime} \mathrm{E}, 51^{\circ} 26^{\prime} 27.5^{\prime \prime} \mathrm{N}$; in the east, $73^{\circ} 10^{\prime} 11.4^{\prime \prime} \mathrm{E}, 50^{\circ} 24^{\prime} 32.3^{\prime \prime} \mathrm{N}$ (Figure 1 ). The digital elevation model (DEM) is based on the Shuttle Radar Topography Mission (SRTM) data [42].

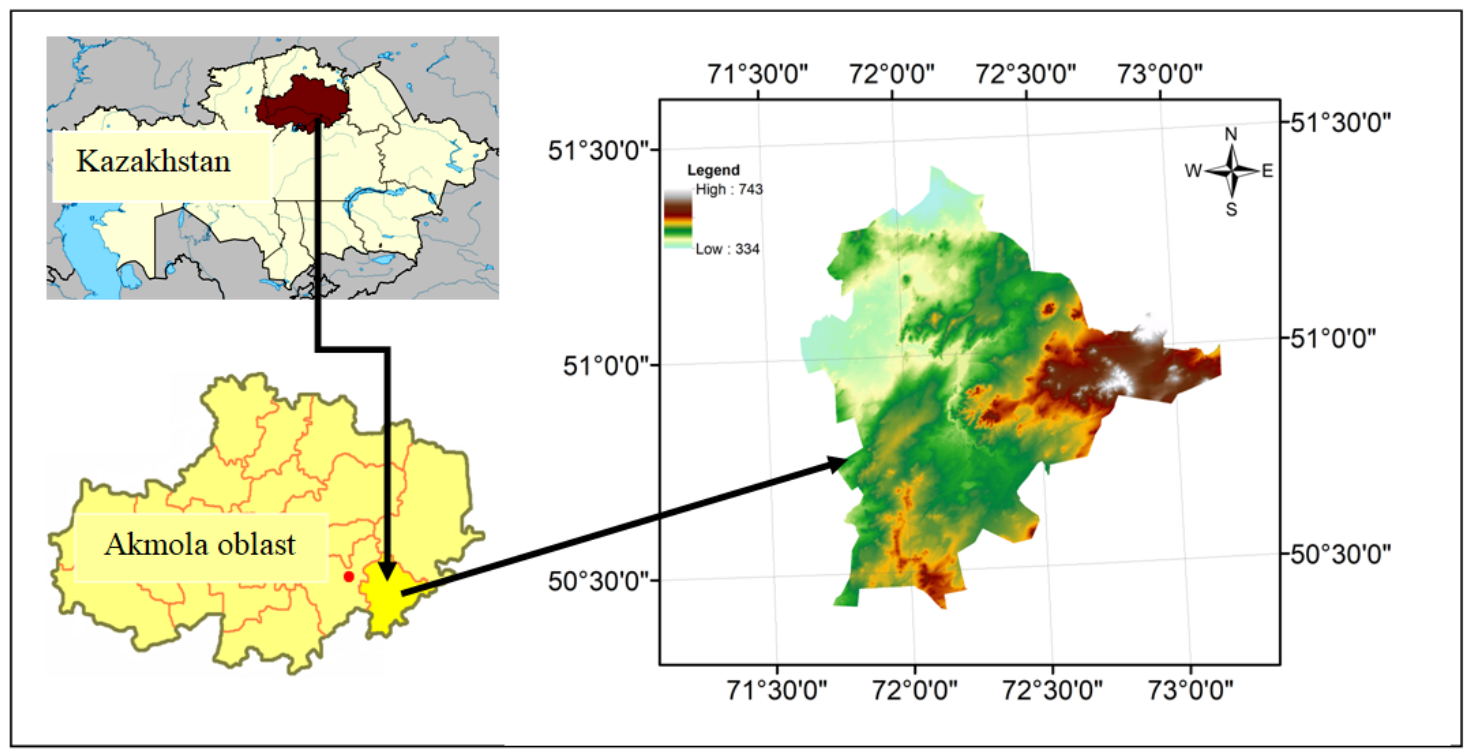

Figure 1. Location and digital elevation map of the study area.

The study areais located within the Kazakh Uplands, with low mountainous relief in the east. The central part is hilly; the north and west are characterized by a slightly undulating plain. In the eastern part of the AOI, natural birch-aspen trees are often found. The climate of the study area is continental and is part of the dry steppe zone. Winters are cold and lengthy, with an average temperature of $-17^{\circ} \mathrm{C}$ in January; summers are moderately warm, with an average temperature of $20^{\circ} \mathrm{C}$ in July. The average annual rainfall is $300-350 \mathrm{~mm}$. The Esil River flows through the district; its length, including the small tributaries in the district, is $125 \mathrm{~km}$. Most of the small rivers dry up in the summer. There are more than forty large and small lakes. In the district, there are three artificial reservoirs, namely, Astana, Kenetay, and Bersuat. The water levels of these reservoirs are subject to seasonal changes; they increase in spring and decrease in autumn, but the surface area of the reservoirs themselves hardly change. Arshaly district is one of the leading agricultural areas of the Akmola region. The main agricultural activity of the region is grain production. The Nur-Sultan-Karagandy and Nur-Sultan-Pavlodar railroads as well as the republican-level Nur-Sultan-Karaganda highway pass through the Arshaly district. The Arshaly district covers an area of 584.7 thousand ha, of which 469.8 thousand ha areagricultural land. The centre of the district is located in the relatively large village of Arshaly. There are 12 rural cantons (separate territorial units with local jurisdiction but within the district administration) and 35 settlements, including small railway stations, which have terminals for receiving and storing grain [43]. The population of the district in 2019 was 27,404 people [44].

\subsection{Data}

Landsat 5 and 8 multispectral data obtained from the United States Geological Survey website [45] were used to study changes in LULC in the AOI. Landsat images (spatial resolution $30 \mathrm{~m}$ ), geometrically corrected to UTM (Universal Transverse Mercator), zone 42 to the north, and WGS-1984 (World Geodetic System), were used. As shown in Table 1, each satellite dataset has information about four spectral bands that correspond to blue (B), green $(\mathrm{G})$, red (R), and near-infrared (NIR). We used the false color composite (FCC), consisting of the four channels B, G, R, and NIR, received from the Landsat 5 and 8 satellites as well as color-balanced mosaics based on them from two unclouded images that cut along 
the border of the district. Images were used to identify and classify agricultural land and built-up areas in the study area in the multi-time periods of 1998, 2008, and 2018.

Table 1. Satellite images and their characteristics.

\begin{tabular}{|c|c|c|c|c|c|}
\hline Satellite & Sensor & Year/Month/Day & No. of Bands & Spectral Composition & Wavelength $(\mu \mathrm{m})$ \\
\hline \multirow{4}{*}{ Landsat 5} & \multirow{4}{*}{$\mathrm{TM}$} & & 1 & Visible Blue & $0.45-0.52$ \\
\hline & & 1998/09/17 & 2 & Visible Green & $0.52-0.60$ \\
\hline & & 1998/09/17 & 3 & Visible Red & $0.63-0.69$ \\
\hline & & & 4 & NIR & $0.76-0.90$ \\
\hline \multirow{4}{*}{ Landsat 5} & \multirow{4}{*}{$\mathrm{TM}$} & & 1 & Visible Blue & $0.45-0.52$ \\
\hline & & $2008 / 07 / 26$ & 2 & Visible Green & $0.52-0.60$ \\
\hline & & $2008 / 07 / 26$ & 3 & Visible Red & $0.63-0.69$ \\
\hline & & & 4 & NIR & $0.76-0.90$ \\
\hline \multirow{4}{*}{ Landsat 8} & \multirow{4}{*}{ OLI } & & 2 & Blue & $0.45-0.51$ \\
\hline & & 2018/05/19 & 3 & Green & $0.53-0.59$ \\
\hline & & $2018 / 05 / 19$ & 4 & Red & $0.63-0.67$ \\
\hline & & & 5 & NIR & $0.85-0.88$ \\
\hline
\end{tabular}

\subsection{Ancillary Data}

To compile basic maps and to interpret RS data, thematic maps were used by the Automated Information System of the State Land Cadastre [46], which in turn were obtained from the National Cartographic and Geodetic Fund of the Republic of Kazakhstan [47]. Based on these, geodatabases were compiled, which were used to collect training samples, to conduct ground-truthing, to evaluate the accuracy of the classification, and to determine the real ownership of land.

\subsection{Methods for Classifying and Accuracy Assessment}

For the first level of classification, the following five LULC classes were used according to CORINE [48], as seen in Table 2: arable land, pastures, water, forest, and built-up areas.

Table 2. Land-use and land-cover (LULC) classes of the study area.

\begin{tabular}{cc}
\hline Level 1 & Level 2 \\
\hline Arable land & Wheat, barley, sunflower, alfalfa, different types of fallows \\
\hline Pasture & Pastures, meadows, deposits \\
\hline Forest & Deciduous, coniferous, mixed, forest nurseries, shrubs \\
\hline Built-up area & Settlements, industrial zone \\
\hline
\end{tabular}

We used the supervised classification of the LULC, the task of which was to detect objects of already known types in the images, which required some preliminary knowledge about the studied area of the Earth's surface. The maximum likelihood classifier (ML) was used for the supervised classification in this particular study. The ML classifier is one of the most widely used, extremely simple, and easily implemented algorithm. Moreover, ML is very well known and has already been successfully applied to a broad range of remote-sensing problems $[49,50]$. Therefore, in this particular study, supervised classification was conducted using the image processing software ArcGIS (version 10.6.1) for LULC classification.

After initial supervised classification, the LULC map was edited based on ground verification of doubtful areas and some classes were recoded into their respective classes. Ground-truthing verification was done on those particular areas that were not clear in the classification. In this process, land-use and land-cover maps were prepared initially and the confusing spots were identified. For each class, i.e., arable land, pastures, water, forest, and built-up areas, at least twelve points were 
marked. An exhaustive ground-truthing of the study area was carried out, and some corrections were subsequently made. The ground reference data used for the image classification were further applied for the purpose of accuracy assessment.

After ground-truthing, an accuracy assessment was carried out, which is the most important way to assess the reliability of amap. No image classification is said to be complete unless its accuracy has been assessed. To determine the accuracy of classification, a sample of pixels was selected on the classified image and their class identities were compared with the ground reference data. In this study, the classification error matrix (or confusing matrix) was used, which is acommon means of expressing the classification accuracy. In the error matrix, the overall classification confidence indicator is defined as the number of correctly classified points located along the diagonal of the table (in \%). This number may be random. To take this fact into account when summarizing the results, the so-called coefficient or K (Kappa) index, which corrects for randomness, is often used. Kappa analysis is a discrete multivariate technique that calculates the producer's and user's overall accuracy as well as the Kappa accuracy level.

The Kappa index is calculated by the following formula [51]:

$$
\mathrm{K}=(\mathrm{d}-\mathrm{q}) /(\mathrm{N}-\mathrm{q})
$$

where $\mathrm{d}$ is the number of cases where the result is obtained correctly (the sum of the values on the diagonal of the error matrix) and where $q$ is the number of random results calculated in terms of the number of random results in rows $\mathrm{n}_{\mathrm{c}}$ and true results in columns $\mathrm{n}_{\mathrm{r}}$ of the correspondence matrix, calculated as follows:

$$
\mathrm{q}=\sum \mathrm{n}_{\mathrm{c}} \mathrm{n}_{\mathrm{r}} / \mathrm{N}
$$

where $\mathrm{N}$ is the total number of points.

For absolutely accurate results (all $\mathrm{N}$ points on the diagonal), Kappa is 1, and for a purely random hit, Kappa is 0.

After accuracy assessment and correction, the class-wise areas of the 1998, 2008, and 2018 mosaics were calculated. In LULC classification, change detection is a very important process, which was done after the completion of the calculation and analysis of the land-use land-cover classes from the 1998, 2008, and 2018 mosaics. By using the change-detection option in ArcGIS software, the differences between the three mosaics of the Arshaly district for all five LULC classes were computed. The integral structure of the methodological approach that we used is shown in the block diagram in Figure 2.

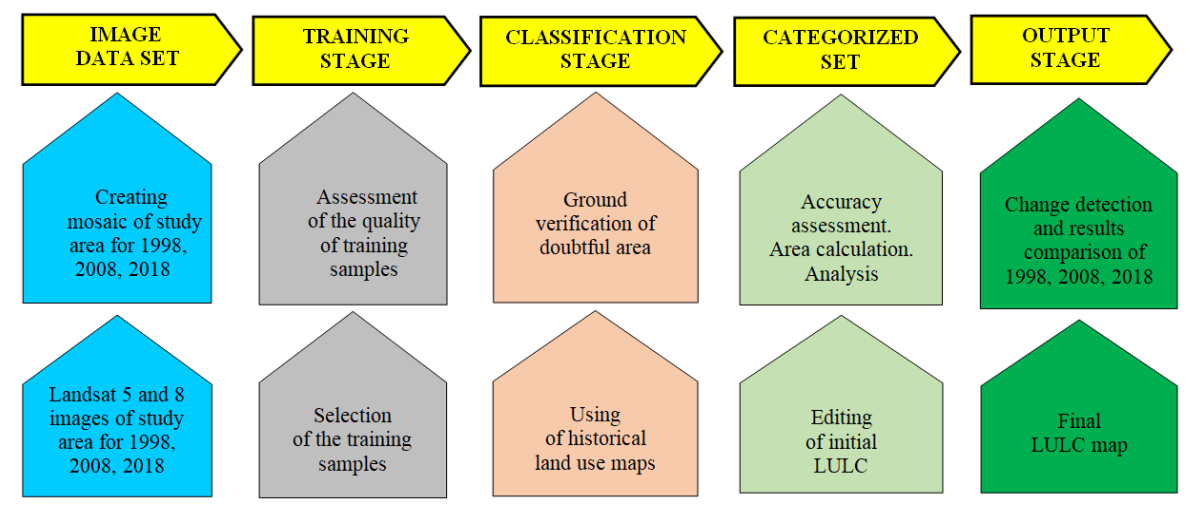

Figure 2. Methodology for LULC map generation.

Thus, the methodological approaches we used to classify LULC and to evaluate its accuracy were repeatedly tested and found reliable enough to be able to automate these processes. 


\section{Results}

\subsection{Overall LULC Changes}

The results of the classification of the LULC change showed that the area of agricultural land (arable land and pastures) as well as water bodies, forests, and built-up areas over the years of the research underwent relative changes, as shown on the LULC maps of 1998, 2008, and 2018 (Figure 3).

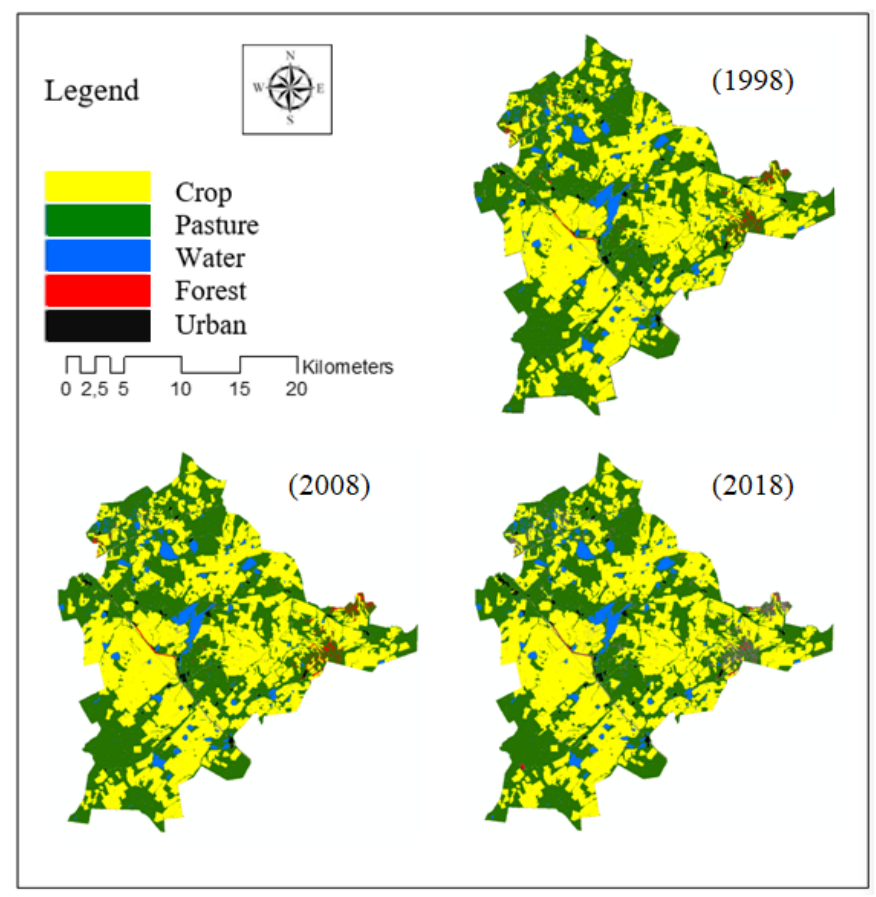

Figure 3. LULC map of the Arshaly district after classification of Landsat mosaics in 1998, 2008, and 2018 into five classes: arable lands, pastures, water, forest, and built-up areas. Agricultural lands occupies the main part of the study area ( 95\%) (arable lands: $2747.0-2797.2 \mathrm{~km}^{2}$, pastures: $2634.4-2698.8 \mathrm{~km}^{2}$ ), water: $\sim 3.8-3.9 \%$, forests: $\sim 0.8-0.9 \%$, and built-up areas: $\sim 0.5-0.6 \%$.

Examples of changes in the LULC class areas from 1998 to 2018 are shown in Figure 4.

The results of the LULC classification for the 1998-2018 period are shown in Table 3, which indicates that, during the years of observation, about $95 \%$ of the area was occupied by arable land and pastures. For example, in 1998, they were 94.9\%; in 2008, they were $94.8 \%$; and in 2018, they were $94.6 \%$. At the same time, there were marked changes in the composition of these two land-use groups. We found a steadily increasing trend in the area of arable land, mainly through the ploughing of pastures. From 1998 to 2008, the areas occupied by arable land increased by $1.0 \%$ or $28.9 \mathrm{~km}^{2}$ and, from 2008 to 2018 , by $0.8 \%$ or $21.3 \mathrm{~km}^{2}$. At the same time, the rangelands of the district decreased by $1.3 \%$ or $35.2 \mathrm{~km}^{2}$ from 1998 to 2008 and by $1.1 \%$ or $29.2 \mathrm{~km}^{2}$ from 2008 to 2018 . Over the entire observation period, the area of pastures decreased by $2.4 \%$ or $64.4 \mathrm{~km}^{2}$, of which $50.2 \mathrm{~km}^{2}$ was developed for arable land. A typical example of the expansion of arable areas due to the ploughing of pastures is shown in Figure $4 \mathrm{~A}$.

The area of water bodies that united more than forty small and medium-sized lakes in different years amounted to 3.8-3.9\%. Relatively small changes in the area of water bodies were mainly associated with the seasons when Landsat images of the study area were obtained. Thus, Landsat images from 1998 were used, which were taken in the fall (September), and from 2008, which were from the end of July when the water bodies were shallow due to evaporation during the hot periods of the year, as seen in Figure 4B. Images of the administrative area in 2018 were obtained in the second 
half of spring (May) during the period of the maximum catchment by water bodies. Therefore, in 2018, the maximum area of the AOI's water bodies was noted.
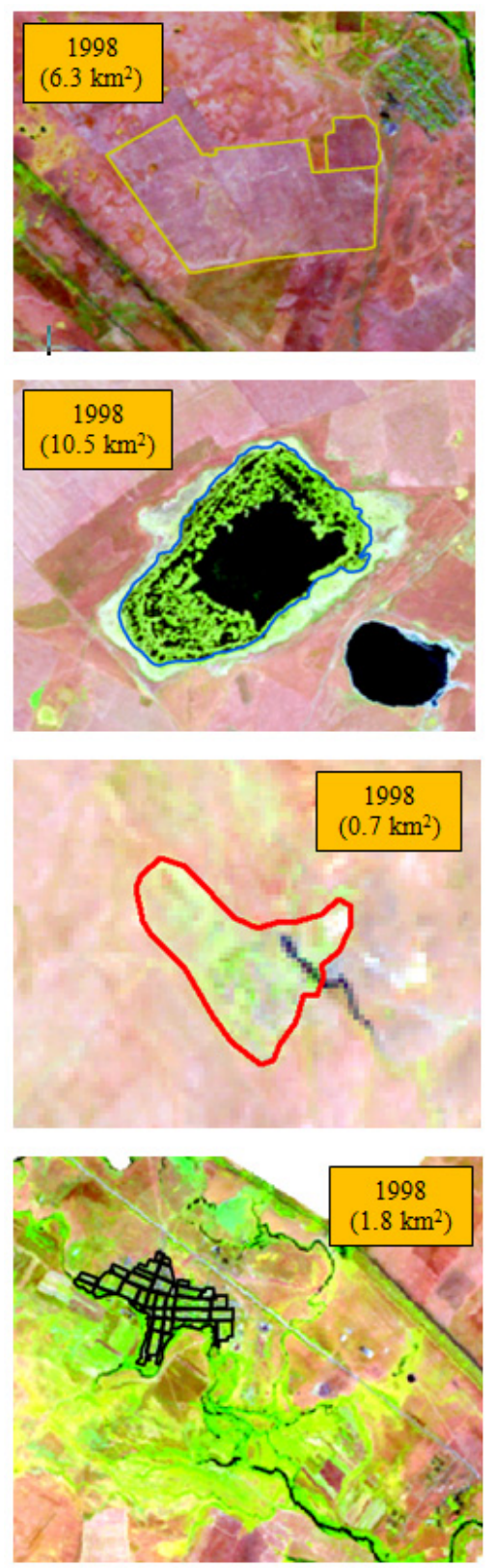

A

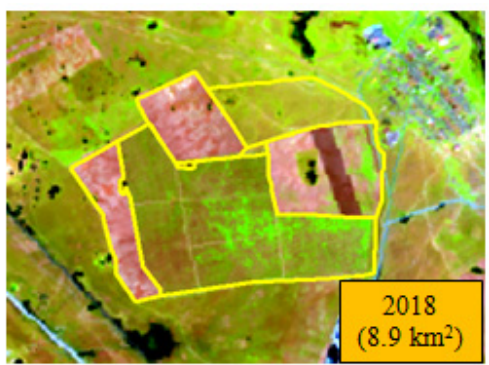

B
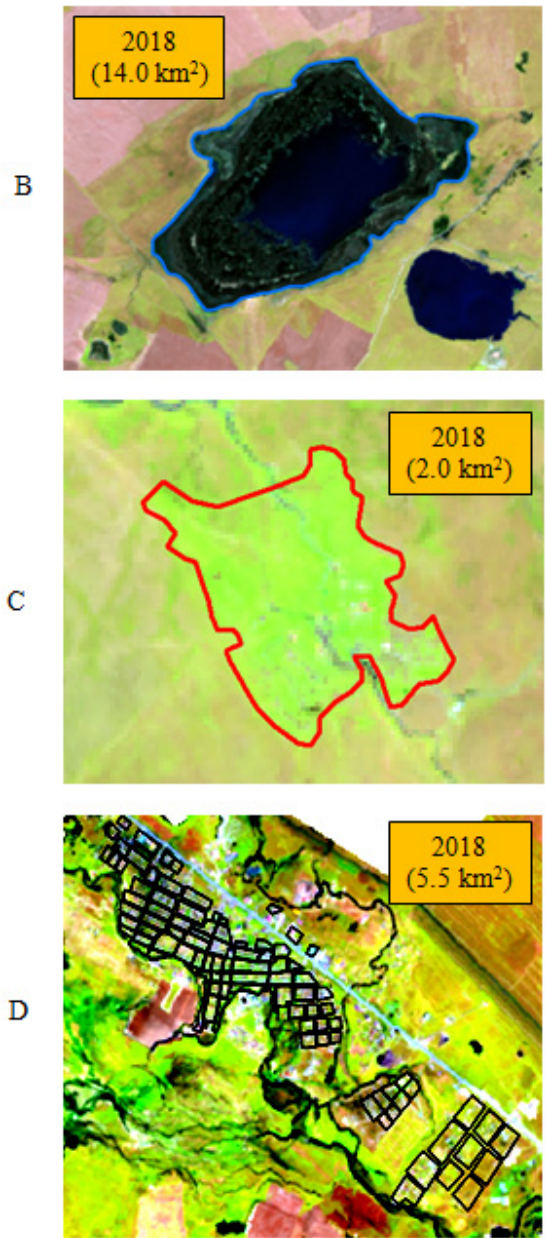

Figure 4. Examples of changes in the LULC class areas from 1998 to 2018: (A) Arable lands, (B) water, (C) forest, and (D) built-up area. 
Table 3. LULC area, area difference, classification accuracy, and Kappa statistics.

\begin{tabular}{|c|c|c|c|c|c|c|c|c|c|}
\hline \multirow{3}{*}{$847+39$} & \multicolumn{6}{|c|}{ Area } & \multicolumn{3}{|c|}{ Area of Difference $\left(\mathrm{km}^{2}\right)$} \\
\hline & \multicolumn{2}{|c|}{1998} & \multicolumn{2}{|c|}{2008} & \multicolumn{2}{|c|}{2018} & \multirow{2}{*}{ 1998-2008 } & \multirow{2}{*}{ 2008-2018 } & \multirow{2}{*}{ 1998-2018 } \\
\hline & $\mathrm{km}^{2}$ & $\%$ & $\mathrm{~km}^{2}$ & $\%$ & $\mathrm{~km}^{2}$ & $\%$ & & & \\
\hline Arable land & 2747.0 & 47.9 & 2775.9 & 48.4 & 2797.2 & 48.7 & 28.9 & 1.0 & 21.3 \\
\hline Pasture & 2698.8 & 47.0 & 2663.6 & 46.4 & 2634.4 & 45.9 & -35.2 & -1.3 & -29.2 \\
\hline Water & 220.8 & 3.8 & 220.5 & 3.8 & 220.8 & 3.6 & -0.3 & -0.1 & 0.3 \\
\hline Forest & 42.8 & 0.8 & 47.3 & 0.8 & 52.3 & 0.9 & 4.5 & 10.5 & 5.0 \\
\hline Built-up area & 30.1 & 0.5 & 32.2 & 0.6 & 34.8 & 0.6 & 2.1 & 7.0 & 2.6 \\
\hline Total & 5739.5 & 100 & 5739.5 & 100 & 5739.5 & 100 & & & \\
\hline Overall accuracy $(\%)$ & & 93.7 & & 92.1 & & 98.3 & & & \\
\hline Kappa & & 0.88 & & 0.87 & & 0.97 & & & \\
\hline
\end{tabular}

Forest areas in the district occupied less than one percent $(0.8-0.9 \%)$. At the same time, we found that the areas used for growing trees increased noticeably, mainly due to the expansion of previously existing forests. For example, in 2008, the area of land occupied by forests was $10.5 \%$ or $4.5 \mathrm{~km}^{2}$ higher than that in 1998 and, in 2018, the area increased by $22.2 \%$ or $9.5 \mathrm{~km}^{2}$. An example of an increase in the area of forest stands can be seen in Figure 4C. It should be emphasized that the increase in the forest area in the region was due to the creation and expansion of the green zone of the capital of the republic.

Urban areas occupied only $0.5-0.6 \%$ of the entire AOI. However, the proximity of the capital of the republic had a significant impact on the change in urban areas. The most profound changes occurred near the border of the capital, the city of Nur-Sultan (Figure 4D). From 1998 to 2008, the urbanized areas of the district increased by $7.0 \%$ or $2.1 \mathrm{~km}^{2}$, and from 2008 to 2018 , the area of increase was $8.1 \%$ or $2.6 \mathrm{~km}^{2}$. For the entire period, i.e., from 1998 to 2018, the total area of settlements compared with the beginning of our observations increased by $15.6 \%$ or $4.7 \mathrm{~km}^{2}$.

\subsection{Classification Accuracy}

The overall accuracy and Kappa coefficient show that the classification results are quite reliable (Table 3). Thus, the overall classification accuracy varied between $92.1 \%$ and $98.3 \%$. The Kappa coefficient for the classified images of 1998 was 0.88 ; for 2008, it was 0.87; and for 2018, it was 0.94 .

For each classified group, the difference in the accuracy between the producers and the users was relatively small (Table 4). For example, for arable land, producer accuracy varied from $93.9 \%$ to $95.9 \%$; for pastures, from $91.7 \%$ to $95.1 \%$; for water, from $98.9 \%$ to $99.5 \%$; for forest, from $94.8 \%$ to $98.8 \%$; and, for built-up areas, from $89.5 \%$ to $96.4 \%$. User's accuracy was found in even smaller intervals and, for all classified groups, varied from $92.0 \%$ to $99.7 \%$. Since the overall accuracy exceeded $90 \%$, the research results could be considered quite acceptable for both the user and the producer. That is, the results of evaluating the classification accuracy and their errors convincingly showed the reliability of the work we performed and paved the way for automating thematic mapping processes for LULC classification results. 
Table 4. Producer's and user's accuracy of LULC classification of study area.

\begin{tabular}{ccccccc}
\hline \multirow{2}{*}{ *LULC Classes } & \multicolumn{2}{c}{ 1998 } & \multicolumn{2}{c}{ 2008 } & \multicolumn{2}{c}{2018} \\
\cline { 2 - 6 } & Producer's & User's & Producer's & User's & Producer's & User's \\
\hline 1 & 95.3 & 92.0 & 93.9 & 95.1 & 95.9 & 95.3 \\
\hline 2 & 91.7 & 95.0 & 94.8 & 93.5 & 95.1 & 95.7 \\
\hline 3 & 98.9 & 96.7 & 99.2 & 99.7 & 99.5 & 99.7 \\
\hline 4 & 94.8 & 96.1 & 98.8 & 97.6 & 98.8 & 96.4 \\
\hline 5 & 89.5 & 96.2 & 98.2 & 96.4 & 96.4 & 98.2 \\
\hline
\end{tabular}

\section{Discussion}

The approach we adopted of using Earth observation systems to estimate the spatiotemporal changes in LULC is at present the most common. This is confirmed by the fact that, based on this approach, semiautomatic tracking systems for LULC are created at the global [52], regional [53], and national [54] levels, which indicate the methodological validity of the direction of our work.

The process of urban expansion as well as changes in the land-use structure of the PUA is caused by many factors and is a complex socioeconomic process that goes through several stages, namely stagnation (control of urbanization), acceleration (openness to urbanization), etc. [55]. The composition and strength of the influence of these factors on the dynamics of LULC vary depending on the history of events and the prevailing situations in the particular region and country being studied [56-58]. We conducted the first assessment of LULC change in the Arshaly agro-industrial district of Akmola Oblast in 20 years, which is the PUA of the Nur-Sultan metropolis. Our results showed strong spatial and temporal dynamics of LULC from 1998 to 2018. Next, we considered the role of the most significant factors influencing LULC change and sustainable development of the study area, taking into account the results of our work as well as those of others.

\subsection{Urban Sprawl and Population Growth}

Urbanization is becoming a global trend [59], and it is expected that, by 2050, 68 percent of the world's population will be urban dwellers. An increase in the number of urban residents is usually accompanied by expansion of the city into agricultural land [60]. Kazakhstan is no exception [61]. At the present stage, Kazakhstan is characterized by intensive growth in the number and proportion of the urban population. During the 1996-2015 period, the level of urbanization in the country increased from $55.8 \%$ to $57.0 \%$ and the urban population increased by $16.6 \%$. A feature of Kazakhstan is an increase in the population of large cities, while the population in medium-sized and small cities is decreasing. One of the areas of economic growth and, accordingly, the attraction of migrants is the city of Nur-Sultan. As the capital, it is the center of the resettlement systems of international, national, interregional, and regional significance. It combines them with transport systems and forms the supporting spatial framework of the country [62]; all of this is accompanied by urban expansion. For example, strong land expansion by the city of Nur-Sultan was shown in Reference [41]. From 1992 to 1999, the pace of urban development was relatively low. The largest expansion of the built-up areas of the capital occurred from 1999 to 2010, when growth occurred mainly in the central part of the city. At approximately the same pace, the expansion of land by the megalopolis continued from 2010 to 2016, and this period was characterized by the appropriation of mostly marginal areas. By 2018, the increase of new developments in the main city of the republic slowed down but continued [63]. In general, the area of land occupied by this metropolis from 1998 to 2018 increased almost three fold—from $258 \mathrm{~km}^{2}$ to $797.3 \mathrm{~km}^{2}$ [5] —and this happened as a result of the seizure of land that had been used for the most part for agricultural purposes. Along with the land expansion, there was an 
increase in the population of the capital [64]. From 1992 to 1998, i.e., during the six years preceding the formation of the new capital of Kazakhstan, the number of city residents remained almost unchanged. A noticeable increase in the city's population occurred four years later (2002) after the regional city was declared the main city of the country. In subsequent years (2005-2019), there was a strong positive trend in population growth.

\subsection{Peri-Urban Area}

In the PUA, the share of arable land has been steadily increasing since 1998 (Table 3). Apparently, these lands were open until the collapse of the USSR. However, at the beginning of Kazakhstan's transition to a market economy, many lands were abandoned or at least they were not ploughed and were used mainly as pastures $[65,66]$. The reason for not ploughing the land is the socioeconomic situation prevailing not only in Kazakhstan but also in many post-communist countries from 1990 to about the beginning of 2000 [67-70]. The development of this phenomenon was facilitated by the loss of a guaranteed grain sales markets and by the deterioration of price relations between the value of manufactured products and their sale during the transition period. One of the important factors was the mass migration of nonindigenous people to the territory of the republic who came to Kazakhstan as a result of developing virgin lands [71]. For example, the population of the Arshaly district center constantly decreased from 1989 to 2004 [72]. After approval by the capital of the republic of the city of Nur-Sultan (Astana), the population decline stopped. A second rise in the number of villagers in the village occurred in 2009 when the most effective economic transformations were taking place in the country [73]. However, apparently due to the attraction of the metropolis, a steady outflow of the population subsequently occurred. This situation as described is typical of PUAs for almost all major urban metropolitan areas of Kazakhstan [61]. One of the driving factors for increasing the share of arable land in the Arshaly district is primarily the proximity of the Nur-Sultan metropolis. The economic activity of this fast-growing metropolis has contributed to an increase in land-use intensity without population growth.

\subsection{Accessibility}

Transport accessibility is assumed to be the main driver of urbanization [74-76] and city extensions intothe PUA. Accessibility is usually assessed in terms of connecting the AOI to transportation infrastructure (roads, railways, and airways), which facilitate communication with the main metropolitan area. A significant part of the urban expansion is likely to occur as a result of the improvement of the Nur-Sultan roads, which are attractive for both residents and enterprises. Thus, it is precisely along the axis of the republican-level highway between Nur-Sultan and Karaganda on the border with the Arshaly district and the metropolis that there was a strong increase in the built-up area (Figure 4D).

\subsection{Economic and Legal Factors}

Economic growth is one of the main drivers [59] that push urban expansion into the PUA. For example, affordable land in the PUA attracts new immigrants. The expansion process in the PUA is very beneficial when the price of the converted land (from agriculture to buildings) is several times higher than the price of the same agricultural land. Besides, almost all agricultural land in the PUA is available for market transactions, so agricultural land is relatively easy to buy and sell [77]. For these reasons, land speculation is very common in these areas. The same is true for the study area [78]. On the other hand, since urban expansion into agricultural land is officially limited [79], the government of the republic cannot speed up planning procedures to manage urban expansion in the PUA [80]. In terms of the governance of the city of Nur-Sultan, the seizure of land within the PUAfor urban development is carried out exclusively through the decrees of the President of Kazakhstan, which is a rather complicated process. In addition, at the level of the country's government, a system of measures was adopted, aimed at the sustainable development of the Astana (Nur-Sultan) agglomerations along 
with their PUAs [81]. These measures are aimed at restraining the growth of the city and at improving the environment, including the creation of a green framework around urban agglomerations in the form of forest stands $[82,83]$, which explains the increase in the forested area in the AOI.

\section{Conclusions}

We studied the spatiotemporal changes of LULC of the Arshaly district, which is within the PUA of the fast-growing metropolis Nur-Sultan. Using multitemporal Landsat images for 1998, 2008, and 2018, five categories of land were classified (arable land, pastures, water bodies, forest, and built-up areas). As a result, the main trends of the influence of the fast-growing large city on the change in the structure of the LULC in the agricultural district were identified. During the observation period, the following observations were made: there was a significant increase in arable land and a decrease in pasture land; the area of water bodies varied within the seasons, but no general trend of their increase or decrease was found; a steady increase in the area occupied by forest stands was noted; and the most active increase in built-up territories was observed on the border of the Arshaly district with the capital of the republic. The results obtained were reliable and are characterized by fairly high accuracy.

The analysis of factors influencing the sustainable development of the AOI showed that the most powerful drivers of the impact of the Nur-Sultan metropolis on the Arshaly district are the expansion of agricultural land; city population growth; development of transport infrastructure, which increases the accessibility of the city for new residents; and the systems of economic and legislative measures aimed at preventing the spontaneous development of urban sprawl. On the other hand, the increase in the area of cultivated land in the PUA is due to their abandonment after the collapse of the former USSR, which was caused by the economic recession and by the outflow of the population from the countryside to the city. In general, the system of measures adopted at the state level was aimed at the sustainable development of the Arshaly district.

The results of our research, based on the use of RS and GIS, are of considerable value. They contribute to the detection of changes in the composition of LULC in a semiautomatic mode and are useful for local residents, governments, and researchers in difference fields for the rapid identification and assessment of phenomena and processes in PUAs that do not correspond to the sustainable development of the study area. Overall, this study provides evidence that integrating GIS and open-access RS data constitutes a useful approach for the provision of baseline spatial information. Such spatial information is crucial for informed land-use planning to improve environmental sustainability.

Author Contributions: Conceptualization, O.A. and Ch.A.; methodology, O.A.; formal analysis, A.S. and Zh.T.; investigation, M.A., N.M., and K.A.; writing-original draft preparation, O.A. and Ch.A.; visualization, M.A., N.M., and K.A.; supervision, O.A. All authors have read and agreed to the published version of the manuscript.

Funding: This research was funded by The Committee of Science of the Ministry of Education and Science of the Republic of Kazakhstan under grant number 242 of 03/27/2018 and by The ERASMUS+ Programme of the European Unionwithin the framework of the Project "New and Innovative Courses for Precision Agriculture" (NICOPA) (project reference number 597985-EPP-1-2018-1-KZ-EPPKA2-CBHE-JP); however, this document reflects the views only of the authors, and the Commission cannot be held responsible for any use thatmay be made of the information contained herein.

Conflicts of Interest: The authors declare no conflict of interest.

\section{References and Notes}

1. Urban Sprawl in Europe Joint EEA-FOEN Report. 2016, Volume 11, p. 140. Available online: https: //www.eea.europa.eu/publications/urban-sprawl-in-europe (accessed on 7 January 2020).

2. Goswami, M. Conceptualizing Peri-Urban-Rural Landscape Change for Sustainable Management. Available online: http://www.isec.ac.in/WP\%20425\%20-\%20Mrinalini\%20Goswami\%20-\%20Final.pdf (accessed on 10 January 2020).

3. Jiang, L.; Deng, X.; Seto, K. The Impact of Urban Expansion on Agricultural Land Use Intensity in China. Land Use Policy. 2013, 35, 33-39. [CrossRef]

4. Tabuchi, T. Agglomeration in World Cities. ProcediaSoc. Behav. Sci. 2013, 77, 299-307. [CrossRef] 
5. Nur-Sultan City Akimat. Available online: http://astana.gov.kz/en/ (accessed on 3 January 2020).

6. Alipbeki, O.; Alipbekova, C. Development of Spatial Data Infrastructure of Agroindustrial Agglomeration. In Proceedings of the International Conference on GIS and Remote Sensing in Agriculture, Copenhagen, Denmark, 11-12 June 2019; p. 761.

7. Suleimenov, M. Trends in the Agriculture of Central Asia and Implications for Rangelands and Croplands. In Novel Measurements and Assessment Tools for Monitoring and Management of Land and Water Resources in Agricultural Landscapes of Central Asia; Environmental Science and Engineering, Springer: Switzerland, 2014; Volume XIII, pp. 91-105. Available online: https://www.springer.com/gp/book/9783319010168 (accessed on 18 February 2020).

8. Dadras, M.; Shafri, Z.H.M.; Ahmad, N.; Pradhan, P.; Safarpour, S. Land Use/Cover Change Detection and Urban Sprawl Analysis in Bandar Abbas City, Iran. Sci. World J. 2014, 690872. Available online: https: //www.ncbi.nlm.nih.gov/pmc/articles/PMC4167654/ (accessed on 18 February 2020). [CrossRef] [PubMed]

9. Doygun, H. Effects of urban sprawl on agricultural land: A case study of KahramanmaraAY, Turkey. Environ. Monit. Assess 2008. [CrossRef] [PubMed]

10. Mulugeta, M.; Tesfaye, B.; Ayano, A. Data on Spatiotemporal Land Use Land Cover Changes in Peri-Urban Addis Ababa, Ethiopia: Empirical Evidences from Koye-Feche and Qilinto Peri-Urban Areas. Data Brief. 2017, 12, 380-385. [CrossRef] [PubMed]

11. Mundhe, N.; Jaybhaye, R. Impact of urbanization on land use/land covers change using Geo-spatial techniques. Int. J. Geomat. Geosci. 2014, 5, 50-60.

12. Hu, Y.; Kong, X.; Zheng, J.; Sun, J.; Wang, L.; Min, M. Urban Expansion and Farmland Loss in Beijing during 1980-2015. Sustainability 2018, 10, 3927. [CrossRef]

13. Lutzenberger, A.; Brillinger, M.; Pott, S. Global Land-Use Analysis. LeuphanaUniversitätLüneburg, Institute for Sustainable and Environmental Chemistry. Available online: https:/globalands.ecologic.eu/sites/default/ files/Land\%20Use\%20Analysis\%20final\%20en.pdf (accessed on 18 February 2020).

14. Manakos, I.; Braun, M. Land Use and Land Cover Mapping in Europe: Practices E Trends; Springer: New York, NY, USA, 2014; p. 441.

15. Antrop, M. Land Use Changes Affected By Urban and Industrial Development. Land use, land cover and soil sciences. Encycl. Life Support Syst. 2009, 1, 169-183.

16. Mbau, J.; Nyangio, M.; Gachene, C. Land Use and Land Cover Change Analysis: Linking Local Communities to Land Use and Land Cover Changes Using Participatory Geographic Information Systems (PGIS). Lambert; Academic Publishing: Cambridge, MA, USA, 2013; p. 96.

17. Diogo, V.; Koomen, E. Land Cover and Land Use Indicators: Review of Available Data. OECD Green Growth Papers. 2017. Available online: https://www.researchgate.net/publication/320064438_Land_Cover_and_ Land_Use_Indicators_Review_of_available_data (accessed on 18 February 2020).

18. Diao, X.; Magalhaes, E.; Silver, J. Cities and rural transformation: A spatial analysis of rural livelihoods in Ghana. World Dev. 2019, 121, 141-157. [CrossRef]

19. Samuel, D.; Leke, O.; Immaculata, N. Urban Sprawl and Loss of Agricultural Land in Peri-urban Areas of Lagos. Reg. Stat. 2016, 5, 20-33. [CrossRef]

20. Wu, Y.; Wang, H.; Wang, Z.; Zhang, B.; Burghard, C.; Meye, B.C. Knowledge Mapping Analysis of Rural Landscape Using Cite Space. Sustainability 2020, 12, 66. [CrossRef]

21. Juliev, M.; Pulatov, A.; Fuchs, S.; Hübl, J. Analysis of Land Use Land Cover Change Detection of Bostanlik District, Uzbekistan. Pol. J. Environ. Stud. 2019, 28, 3235-3242. [CrossRef]

22. Hu, Y.; Hu, Y. Land Cover Changes and Their Driving Mechanisms in Central Asia from 2001 to 2017 Supported by Google Earth Engine. Remote Sens. 2019, 11, 554. [CrossRef]

23. Chen, Q.; Li, Y.; Liu, C.; Yang, Y.; Wu, J.; Li, M. Spatio-Temporal Variation in Mountainous Landscape Changes: A Case Study of Shizhu County. Sustainability 2019, 11, 2131. [CrossRef]

24. Nath, B.; Niu, Z.; Singh, R.P. Land Use and Land Cover Changes, and Environment and Risk Evaluation of Dujiangyan City (SW China) Using Remote Sensing and GIS Techniques. Sustainability 2018, 10, 4631. [CrossRef]

25. Enoguanbhor, E.C.; Gollnow, F.; Nielsen, J.O.; Lakes, T.; Walker, B.B. Land Cover Change in the Abuja City-Region, Nigeria: Integrating GIS and Remotely Sensed Data to Support Land Use Planning. Sustainability 2019, 11, 1313. [CrossRef] 
26. Sultangazin Umirzak Makhmutovich. Selected Works 1996-2006; Space Research Institute: Almaty, Kazakhstan, 2006; p. 420. (In Russia)

27. Zakarin, E.A.; Mirkarimova, B.M.; Dedova, T.V. Geoinformation Models of Atmospheric Pollution of the Aral-Caspian Region of Kazakhstan; CaTa: Almaty, Kazakhstan, 2007; 108p. (In Russia)

28. Kazakhstan Space Research. Space research and experiments of the Republic of Kazakhstan (2005-2007); LLP Dyke-Press: Almaty, Kazakhstan, 2008; Volume 2, p. 240. (In Russia)

29. Kazakhstan Space Research. Applied Space Research in Kazakhstan; Musabaev, T., Zhantayev, Z., Eds.; LLP Dyke-Press: Almaty, Kazakhstan, 2010; Volume 6, p. 368. (In Russia)

30. Akhmedov, D.S.; Zhantaev, Z.S.; Moldabekov, M.M.; Muratova, N.R.; Musabaev, T.A.; Spivak, L.F.; Sultangazin, U.M. Fundamental and Applied Research on the Development and Implementation of Modern Space Technologies in the Interests of Socio-Economic Development of the Republic of Kazakhstan for 1994-2009; Zhantayev, Z.S., Ed.; Triumph "T": Almaty, Kazakhstan, 2011; p. 160. (In Russia)

31. Alipbeki, O.; Kabzhanova, G.; Kurmanova, G.; Alipbekova, C. Application of GIS Technology to Monitor the Secondary Radioactive Contamination of the Degelen Mountain Massif. In Proceedings of the 8th IGRSM International Conference and Exhibition on Geospatial and Remote Sensing, Kuala Lumpur, Malaysia, 13-14 April 2016; Available online: //http://iopscience.iop.org/article/10.1088/1755-1315/37/1/012080/meta (accessed on 18 February 2020).

32. Alipbeki, O.; Kabzhanova, G.; Alipbekova, C. Carrying out space monitoring of agricultural production in North Kazakhstan. Eurasian Union Sci. 2016, 23, 153-156.

33. KGS. Available online: https://www.gharysh.kz/AboutKA_DZZ/ (accessed on 18 February 2020).

34. Kabzhanova, G.; Baktybekov, K.; Aimbetov, A.; Kurmasheva, A.; Kabdulova, G. Remote Monitoring of the Main Types of Soil in Northern Kazakhstan. Seventh International Conference on Remote Sensing and Geoinformation of the Environment. 27 June 2019. Available online: https:/www.spiedigitallibrary.org/conference-proceedings-of-spie/11174/111740Q/ Remote-monitoring-of-the-main-types-of-soil-in-Northern/10.1117/12.2533057.short?SSO=1 (accessed on 18 February 2020).

35. Kabdulova, G.; Kabzhanova, G.; Baktybekov, K.; Aimbetov, A.; Aligazhiyeva, L. Satellite Remote Sensing for Monitoring of the Forest Resources of Kazakhstan. Seventh International Conference on Remote Sensing and Geoinformation of the Environment. 27 June 2019. Available online: https://www.spiedigitallibrary.org/conference-proceedings-of-spie/11174/1117406/Satellite-remotesensing-for-monitoring-of-the-forest-resources-of/10.1117/12.2533563.short (accessed on 18 February 2020).

36. Hamidov, A.; Helming, K.; Balla, D. Impact of Agricultural Land Use in Central Asia: A Review. Available online: https://link.springer.com/article/10.1007/s13593-015-0337-7 (accessed on 18 February 2020).

37. Samarkhanov, K.; Abuduwaili, J.; Samat, A.; Issanova, G. The Spatial and Temporal Land Cover Patterns of the Qazaly Irrigation Zone in 2003-2018: The Case of Syrdarya River's Lower Reaches, Kazakhstan. Sustainability 2019, 11, 4035. [CrossRef]

38. Kraemer, R.; Prishchepov, A.V.; Müller, D.; Kuemmerle, T.; Radelof, V.C.; Dara, A.; Terekhov, A.; Frühauf, M. Long-term agricultural land-cover change and potential for cropland expansion in the former Virgin Lands area of Kazakhstan. Environ. Res. Lett. 2015, 10, 054012. [CrossRef]

39. Eisfelder, C.; Markus Niklaus, M.; Kuenzer, C. Net primary productivity in Kazakhstan, its spatio-temporal patterns and relation to meteorological variables. J. Arid Environ. 2014, 103, 17-30. [CrossRef]

40. Taibassarova, Z. Nazarbayev Detection of the Vegetation Change Cover Using Landsat TM5 in the Burabay State National Natural Park, Kazakhstan. Nazarbayev University, Astana. Available online: https: //nur.nu.edu.kz/bitstream/handle/123456789/3190/Taibassarova.PDF?sequence=1\&isAllowed=y (accessed on 18 February 2020).

41. Ilyassova, A.; Kantakumar, N.L.; Boyd, D. Urban growth analysis and simulations using cellular automata and geo-informatics: Comparison between Almaty and Astana in Kazakhstan. Geocarto Int. 2019. [CrossRef]

42. SRTM Data. Available online: http://srtm.csi.cgiar.org/ (accessed on 15 October 2019).

43. Arshaly District. National Encyclopedia; Kazakh Encyclopedia: Almaty, Kazakhstan, 2004; Volume1, p. 720. (In Russia)

44. Arshaly District Akmola Oblast. Available online: http://arshaly.akmo.gov.kz/ (accessed on 12 January 2020).

45. United States Geological Survey. Available online: https://earthexplorer.usgs.gov/ (accessed on 18 February 2020). 
46. Automated Information System of the State Land Cadastre and Technical Support. Available online: http://www.aisgzk.kz/aisgzk/en/content/maps/ (accessed on 18 February 2020).

47. National Cartographic and Geodesic Fund. Available online: http://nkgf.kz/ (accessed on 18 February 2020).

48. Bossard, M.; Feranec, J.; Otahel, J. CORINE Land Cover Technical Guide-Addendum. 2000. Technical Report No. 40/2000. Copenhagen. Available online: https://www.eea.europa.eu/publications/tech40add (accessed on 9 January 2020).

49. Kaul, H.A.; Sopan, I.T. Land Use Land Cover Classification and Change Detection Using High-Resolution Temporal Satellite Data. J. Environ. 2012, 1, 146-152.

50. Nguyen, T.B.P.; Zhang, X.; Wu, W.; Liu, H. Land Use/Land Cover Changes from 1995 to 2017 in Trang Bang, Southern Vietnam. Agric. Sci. 2019, 10, 413-422. [CrossRef]

51. Lurie, I.K.; Kosikov, A.G. Theory and Practice of Digital Image Processing; Berlyant, A.M., Ed.; Scientific World: Moscow, Russia, 2003; p. 168.

52. USGS EROS Archive-Land Cover Products-Global Land Cover Characterization (GLCC). Available online: https://www.usgs.gov/centers/eros/science/usgs-eros-archive-land-cover-products-global-land-covercharacterization-glcc?qt-science_center_objects=0\#qt-science_center_objects (accessed on 18 February 2020).

53. CORINE Land Cover. Available online: https://land.copernicus.eu/pan-european (accessed on 18 February 2020).

54. Land Use Land Cover Change (LUCC) Data Set. Available online: http://chinaarchive.tamu.edu/portal/site/ chinaarchive/menuitem.3da14c46c63d9737b5c923d7f00011ca/index.html (accessed on 18 February 2020).

55. Charmes, E. Peri-Urbanisation is not Urban Sprawl. October 2015. Available online: http://www.citego.org/ bdf_dossier-7_en.html (accessed on 18 February 2020).

56. Urbanization, Rural Transformation and Implications for Food Security. Online Consultation on the Background Document to the CFS Forum. Available online: http://www.fao.org/3/a-bl630e.pdf (accessed on 18 February 2020).

57. Li, J.; Yang, Y.; Jiang, N. County-Rural Transformation Development from Viewpoint of Population-Land-Industry in Beijing-Tianjin-Hebei Region under the Background of Rapid Urbanization. Sustainability 2017, 9, 1637. [CrossRef]

58. Miljkovic, J.Z.; Crncevic, T.; Maric, I. Land Use Planning for Sustainable Development of Peri-Urban Zones. SPATIUM International Review. Available online: https://core.ac.uk/download/pdf/27229663.pdf (accessed on 18 February 2020).

59. World Urbanization Prospects: The 2018 Revision. United Nations, Department of Economic and Social Affairs, Population Division. Available online: https://population.un.org/wup/Publications/Files/WUP2018Report.pdf (accessed on 18 February 2020).

60. Krannich, J.M. A Modern Disaster: Agricultural Land, Urban Growth, and the Need for a Federally Organized Comprehensive Land Use Planning Model. Cornell J. Law Public Policy 2006, 16, 45.

61. National Report of the Republic of Kazakhstan on Housing and Sustainable Urban Development. Available online: http://habitat3.org/wp-content/uploads/National-Report-of-the-Republic-of-Kazakhstan-Russian$\%$ D0\%86\%D0\%86\%D0\%86.pdf (accessed on 18 February 2020).

62. The Dynamics of the Development of Astana for 18 Years. Available online: https://www.inform.kz/ru/ dinamika-razvitiya-astany-za-18-let_a2927630 (accessed on 18 February 2020).

63. Which Territories Joined Astana. Available online: https://www.zakon.kz/4843303-kakie-territoriiprisoedinili-k-astane.html (accessed on 18 February 2020).

64. The Population of Nur-Sultan. Available online: https://ru.wikipedia.org/wiki/\%D0\%9D\%D0\%B0\%D1\%81\% D0\%B5\%D0\%BB\%D0\%B5\%D0\%BD\%D0\%B8\%D0\%B5_\%D0\%9D\%D1\%83\%D1\%80-\%D0\%A1\%D1\%83\% D0\%BB $\%$ D1\%82\%D0\%B0\%D0\%BD \%D0\%B0 (accessed on 18 February 2020).

65. Agricultural land-cover change in Kazakhstan. Available online: https://www.innovations-report.com/ html/reports/agricultural-sciences/agricultural-land-cover-change-in-kazakhstan.html (accessed on 18 February 2020).

66. Prishchepov, A.V.; Radeloff, V.C.; Dubinin, M.; Alcantara, C. The effect of Landsat ETM/ETM+ image acquisition dates on the detection of agricultural land abandonment in Eastern Europe. Remote Sens. Environ. 2012, 126, 195-209. [CrossRef] 
67. Smith, G. The Post-Soviet States. Mapping the Politics of Transition. Available online: https://www.crcpress. com/The-Post-Soviet-States-Mapping-the-Politics-of-Transition/Smith/p/book/9780340677919 (accessed on 18 February 2020).

68. Osepashvili, I. Land Use Dynamics and Institutional Changes in Central Asia. Available online: http: //www.fao.org/3/ag265e/ag265e00.htm (accessed on 18 February 2020).

69. Zhildikbaeva, A.N.; Sabirova, A.I.; Pentaev, T.; Omarbekova, A.D. Improving the Agricultural Land Use System in the Republic of Kazakhstan. J. Environ. Manag. Tour. 2018, 9, 1585-1592. [CrossRef]

70. Lesiv, M.; Schepaschenko, D.; Moltchanova, E.; Bun, R.; Dürauer, M.; Prishchepov, A.V.; Schierhorn, F.; Estel, S.; Kuemmerle, T.; Alcantara, C.; et al. Spatial distribution of arable and abandoned land across former Soviet Union countries. Scientific Data. Available online: https://www.ncbi.nlm.nih.gov/pmc/articles/PMC5881411/ (accessed on 18 February 2020).

71. McCauly, M. Khrushcev and the development of Soviet agriculture. In The virgin Land Programme 1953-1964; Holms \& Maier: New York, NY, USA, 1976.

72. Arshaly, Akmola Oblast. Available online: https://ru.wikipedia.org/wiki/\%D0\%90\%D1\%80\%D1\%88\%D0\% B0\%D0\%BB $\%$ D1\%8B_(\%D0\%90\%D0\%BA \%D0\%BC\%D0\%BE\%D0\%BB \%D0\%B8\%D0\%BD \%D1\%81\%D0\% BA\%D0\%B0\%D1\%8F_\%D0\%BE\%D0\%B1\%D0\%BB\%D0\%B0\%D1\%81\%D1\%82\%D1\%8C) (accessed on 18 February 2020).

73. Kazakhstan's Economy During the Years of Independence. Available online: https://ibrain.kz/ekonomikakazahstana/ekonomika-kazahstana-v-gody-nezavisimosti (accessed on 18 February 2020).

74. Osman, T.; Prasanna, D.; Takafumi, A. Driving Factors of Urban Sprawl in Giza Governorate of Greater Cairo Metropolitan Region Using AHP Method. Land Use Policy 2016, 58, 21-31. [CrossRef]

75. Bazarbekova, M.; Assipova, Z.; Molgazhdarov, A.; Yessenov, M. Review of transportation modes in Kazakhstan region, Central Asia. Cogent Eng. 2018, 5, 1450799. [CrossRef]

76. Kasraian, D.; Maat, K.; Bert van, W. The impact of urban proximity, transport accessibility and policy on urban growth: A longitudinal analysis over five decades. Urban Anal. City Sci. 2019, 46, 1000-1017. [CrossRef]

77. World Bank Group. A New Growth Model for Building a Secure Middle-Class Kazakhstan. Systematic Country Diagnostic. April 2018. Report No. 125611-KZ. Available online: http://documents.worldbank.org/ curated/en/664531525455037169/pdf/KAZ-SCD-April-2018-FINAL-eng-with-IDU-05012018.pdf (accessed on 18 February 2020).

78. Kulmaganbetova, A.S.; Abuov, K.K.; Akhmetova, N.Z. Development of the Land Market in the Republic of Kazakhstan. Eur. Res. Stud. J. 2018, 21, 545-556. [CrossRef]

79. The Land Code of the Republic of Kazakhstan. Available online: https://online.zakon.kz/document/?doc_ id=1040583 (accessed on 18 February 2020).

80. Kazakhstan Land Administration report. USAID. Available online: https://landportal.org/sites/default/files/ kazakhstanlandadministration.pdf (accessed on 18 February 2020).

81. On approval of the interregional territorial development scheme of the Astana agglomeration (Approved by the Decree of the Government of the Republic of Kazakhstan dated November 8, 2017 No. 726) (In Russia). Available online: https://egov.kz/cms/ru/law/list/P1700000726 (accessed on 18 February 2020).

82. The sixth national report on biological diversity in the Republic of Kazakhstan, Astana. 2018. Available online: https://www.cbd.int/doc/nr/nr-06/kz-nr-06-en.pdf (accessed on 18 February 2020).

83. Green Belt of Astana. Available online: http://astana.gov.kz/en/page/zelenyy_poyas_astany (accessed on 3 December 2019).

(C) 2020 by the authors. Licensee MDPI, Basel, Switzerland. This article is an open access article distributed under the terms and conditions of the Creative Commons Attribution (CC BY) license (http://creativecommons.org/licenses/by/4.0/). 